\title{
Leczenie gorsze od choroby? Diagnoza kondycji polskiego szkolnictwa wyższego na podstawie badań elit polskich uczelni publicznych
}

\begin{abstract}
STRESZCZENIE. Finansowany z publicznych pieniedzy system szkolnictwa wyższego w Polsce jest szeroko postrzegany jako „chory” - niesprzyjający celom, jakie stawiają mu różne grupy społeczne. Istnieje zgoda co do istnienia tego problemu, nie ma natomiast zgody co do diagnozy i metod leczenia. Diagnoza przedstawiona w artykule oparta jest na dwuletnich badaniach elit szkolnictwa wyższego - władz uczelni i przedstawicieli rządu. Według autorki jedną z możliwych przyczyn „choroby” jest polipragmazja - jak w medycynie określa się sytuację, gdy chory konsultuje się jednocześnie z kilkoma lekarzami, którzy stawiają różne diagnozy i przepisują różne leki, mogące wchodzić ze sobą w niepożądane interakcje. Uniwersytet „choruje”, ponieważ ministerstwo i władze akademickie aplikują mu odmienne „lekarstwa”. Podczas gdy władze akademickie podkreślają rolę uniwersytetu w dochodzeniu do prawdy, twórcy polityki naukowej widzą go przede wszystkim jako koło zamachowe gospodarki. Presja ze strony rządu wywołuje zachowania kompensacyjne środowisk akademickich polegające na obchodzeniu przepisów i tworzeniu pozorów. W efekcie cele realizowane przez władze uczelni odbiegają od tych zakładanych w najnowszym polskim prawodawstwie, a bodźce płynące z instytucji politycznych zachęcają do zachowań sprzecznych z etosem akademickim. $Z$ badań wynika jednak, że istnieją trzy obszary potencjalnej synergii, które mogą stać się punktami zwrotnymi w transformacji polskiego szkolnictwa wyższego: kształcenie elitarne, merytoryczne finansowanie badań naukowych oraz kompetencje „miękkie”.
\end{abstract}

SŁOWA KLUCZOWE: uniwersytet, szkolnictwo wyższe, polityka naukowa, modele uczelni, badania jakościowe

\section{Wprowadzenie}

Zdaniem publicystów kształtujących obraz polskiego szkolnictwa wyższego współczesna uczelnia publiczna jest w gorszej kondycji niż za czasów realnego socjali- 
zmu. Studia w wielu polskich szkołach wyższych nie sprzyjają ani bezinteresownemu poszukiwaniu wiedzy, ani zdobywaniu praktycznych kompetencji potrzebnych na rynku pracy (Bendyk 2008; Ozminkowski 2009; Papuzińska 2009; Hartman 2013)1. Podobne opinie utrwalają niektórzy przedstawiciele władz uczelni (Dybczyński 2011; Pacholski 2011) oraz cenione autorytety (Sztompka 2014; Kwiek 2012; Balcerowicz 2014). Choć diagnozy znacznie się różnią, przykład Kongresu Kultury Akademickiej w Krakowie pokazuje, że wśród uczonych i decydentów powszechne jest poczucie kryzysu. Uczestnicy konferencji zorganizowanej przez najstarszy polski uniwersytet $\mathrm{w}$ roku jego jubileuszu 650-lecia uznali zgodnie, że polskie szkolnictwo wyższe jest „chore”. Zdaniem wybitnego historyka Karola Modzelewskiego „choroba” uczelni osiągnęła wręcz skalę „zarazy” (Modzelewski, 2014). Jej symptomy to obniżenie jakości kształcenia, zanik relacji uczeń - mistrz, spadek zaufania społecznego do nauki i naukowców, niepokojące przypadki nierzetelności akademickiej, jeden z najniższych współczynników produktywności badawczej kadry naukowo-dydaktycznej w Europie oraz odpływ najzdolniejszych studentów poza naukę lub do ośrodków naukowych poza Polską².

Podczas gdy naukowcy najlepiej widzą niepokojące symptomy wewnątrz uczelni, dostrzegana przez nich „choroba” odbija się również szerokim echem społecznym. Ponieważ studiuje już ponad 60\% młodzieży (OECD 2011), „choroby” uczelni dotyczą większości polskich rodzin. Dyplom uczelni uznaje się nadal za oznakę prestiżu i gwarancję udanej kariery, ale młodzi ludzie coraz częściej mówią o uczelniach jako „fabrykach bezrobotnych,” które służą przede wszystkim interesom swoich pracowników, a u studentów nie kształtują kompetencji potrzebnych we współczesnym życiu (OBOP 2013). Dla uczestników badań przeprowadzonych w 2013 r. przez Ośrodek Badania Opinii Społecznej metodą grupy fokusowej studia nadal są podstawą starań o godziwe życie, ale nie dają umiejętności, jakie są do takiego życia potrzebne. Masowe studia poszerzają horyzonty, ale i rozbudzają aspiracje, które często okazują się płonne. Dla wielu absolwentów jedynym sposobem na spełnienie tych aspiracji pozostaje emigracja - nie rozważa jej obecnie tylko 17 na 100 Polaków (Newsweek 2014).

Jest zatem zgoda co do istnienia problemu - finansowany z publicznych środków system kształcenia jest szeroko postrzegany jako niesprzyjający celom, jakie stawiają mu różnorodne grupy społeczne. Nie ma natomiast zgody co do diagnozy i zalecanych metod leczenia. Pomimo wielu prób reform nie jest też dotąd jasne, jakimi koncepcjami uczelni kierują się przywódcy i reformatorzy uczelni - przed-

${ }^{1} \mathrm{~W}$ ostatnich latach rzadko zdarzał się miesiąc, w którym nie ukazywałyby się krytyczne teksty dotyczące funkcjonowania polskich uczelni. Wspomniane teksty stanowią jedynie przykłady najszerzej dyskutowanych artykułów.

${ }_{2}^{2}$ Tezy wynotowane podczas obrad Kongresu Kultury Akademickiej, który odbył się w dniach 2022.03.2014 r. na Uniwersytecie Jagiellońskim w Krakowie. Teksty prezentacji konferencyjnych dostępne są na stronie http://kongresakademicki.pl/dzial/teksty-nadeslane/. 
stawiciele wewnętrznych i zewnętrznych ośrodków decyzyjnych w polskim szkolnictwie wyższym, jakimi są władze uczelni, oraz wpływowi eksperci związani z Ministerstwem Nauki i Szkolnictwa Wyższego.

Diagnoza przedstawiona w niniejszym artykule oparta jest na dwuletnich badaniach elit szkolnictwa wyższego - władz uczelni i przedstawicieli rządu. Jednym z celów badania było porównanie koncepcji uczelni publicznych preferowanych przez grupy posiadające na nie największy wpływ. Można postawić tezę, że jedną z możliwych przyczyn „choroby” jest polipragmazja - jak w medycynie określa się sytuację, gdy chory konsultuje się jednocześnie z kilkoma lekarzami, którzy stawiają różne diagnozy i przepisują różne leki, mogące wchodzić ze sobą w niepożądane interakcje. Uniwersytet „choruje”, ponieważ ministerstwo i władze akademickie aplikują mu odmienne „lekarstwa”. W efekcie cele realizowane przez władze uczelni odbiegają od tych zakładanych w polskim prawodawstwie, a bodźce płynące z instytucji politycznych zachęcają do zachowań sprzecznych z etosem akademickim.

\section{Metodologia}

Zbadanie wizji uczelni preferowanych przez elity polskiego szkolnictwa wyższego wymagało opracowania metodologii uwzględniającej zarówno istotę pytania badawczego, jak i charakter wybranej próby. Głównym filarem przyjętej metodologii badawczej był wywiad elitarny, uzupełniony o elementy etnografii.

\subsection{Perspektywa metodologiczna}

W projekcie przyjęto interpretatywne założenie, że ludzie przypisują otaczającemu ich światu różne znaczenia, a proces ich tworzenia jest kluczowym elementem rzeczywistości społecznej (Menzel 1978). Bez względu na ontologiczną czy epistemologiczną zasadność znaczeń i interpretacji przyjmowanych przez współtwórców rzeczywistości społecznej mają one realny wpływ na otaczający ich świat. Jak stwierdzili już w 1927 r. William Thomas i Florian Znaniecki, jeżeli ludzie postrzegają coś jako realne, staje się to realne w swoich konsekwencjach (Thomas i Znaniecki 1927). Rolą badacza jest obserwacja i interpretacja rzeczywistości na zasadach wyznaczonych przez samych uczestników badań (Geertz 1993). Celem niniejszego badania było poznanie nie tylko zachowań i postaw wobec idealnej koncepcji szkoły wyższej, ale także kontekstu, znaczeń i wartości, jakie je kształtują. Ponieważ problem badawczy dotyczy subiektywnych znaczeń i konceptualizacji, wybrano metodologię jakościową, która pozwala na interakcję z uczestnikami badań w ich środowisku społecznym i umożliwia zrozumienie kontekstu, w którym funkcjonują (Guba i Lincoln 2005). 


\subsection{Próba badawcza}

Badanie przeprowadzono w dwóch lokalizacjach: w czterech uczelniach publicznych reprezentujących różne typy instytucjonalne oraz w siedzibie Ministerstwa Nauki i Szkolnictwa Wyższego w Warszawie. Na szczeblu państwowym przeprowadzono dwanaście wywiadów z najwyższymi rangą pracownikami ministerstwa - architektami reform, oraz doradcami eksperckimi.

Główna część badania odbyła się w województwie małopolskim, co było podyktowane czterema względami: 1) stolica województwa jest znanym w całej Polsce ośrodkiem akademickim, w którym znajdują się uczelnie reprezentujące wszystkie typy instytucjonalne nadzorowane przez MNiSW: uczelnia flagowa, techniczna, specjalistyczna i zawodowa; 2) wybór jednego województwa zmniejsza prawdopodobieństwo, że zaobserwowane różnice są regionalne, a nie instytucjonalne; 3) lokalizacja poza Warszawą jest reprezentatywna dla większości uczelni w kraju, podczas gdy uczelnie znajdujące się w pobliżu centralnych instytucji politycznych różnią się od innych zakresem wiedzy o wdrażanych reformach oraz wpływu na ich kształt (Fullan 2001); 4) ponieważ jedynym niezawodnym sposobem przeprowadzenia wywiadów z władzami uczelni jest osobista rekomendacja, a jakość zebranych danych w dużym stopniu zależy od zaufania do badacza, kluczowa w wyborze lokalizacji była pozycja badacza w oczach uczestników badań. Autorka niniejszego artykułu przez wiele lat mieszkała i pracowała w Krakowie, w związku z czym jest znana w miejscowym środowisku naukowym. Znaczenie tego faktu ilustruje proces rekrutacji uczestników badań wśród władz uczelni. Kilka miesięcy przed rozpoczęciem badań władze wybranych uczelni otrzymały z uczelni firmującej badanie (University of Minnesota) oficjalne pismo zapraszające do udziału w badaniu. Nie odpowiedziała na nie ani jedna z tych uczelni. Po dwumiesięcznym pobycie badaczki w Krakowie i jej aktywnym uczestnictwie w życiu akademickim wybranych uczelni ich władze zgodziły się na przeprowadzenie wywiadów. Przeprowadzono w sumie dwadzieścia wywiadów z przedstawicielami władz uczelni, w tym przynajmniej po jednym wywiadzie w każdej uczelni z przedstawicielem kolegium rektorskiego, najwyższego szczebla administracji, oraz senatu akademickiego. Aby chronić tożsamość respondentów, ukryto nazwy trzech uczelni, zaś w przypadku uczelni będącej w regionie jedynym reprezentantem danego typu podjęto dodatkowe środki ostrożności, aby żaden z uczestników badań cytowanych w artykule nie został rozpoznany.

\subsection{Wywiad elitarny z elementami etnografii}

Respondenci o statusie elit niechętnie wypełniają ankiety; rzadko dopuszczają też w swoje otoczenie etnografów, a wywiadów udzielają jedynie wybiórczo. Z tych 
przyczyn główną metodą przyjętą w projekcie był wywiad elitarny. Metoda wywiadu elitarnego wywodzi się z nauk politycznych, gdzie rozwinięto ją najpełniej w badaniach elit rządowych i parlamentarnych. Politolodzy dostrzegli, że respondenci o statusie elit wymykają się łatwo z zamkniętych pytań i kwestionują założenia badacza; doceniają natomiast możliwość przedstawienia swojego punktu widzenia i wyjaśnienia, skąd on pochodzi (Aberbach i Rockman 2002). Wysoki status społeczny takich respondentów wymaga szczególnych technik wydobywających ekspercką wiedzę, pozwalających uczestnikom badania na poprawienie założeń pytającego i współdecydowanie o kierunku rozmowy (Dexter 1970).

Wywiad elitarny ma trzy główne cechy. Po pierwsze, badacz przyjmuje w wywiadzie definicję problemu zaprezentowaną przez samego respondenta. Po drugie, zachęca respondenta, aby to on ustrukturyzował swój opis badanego problemu. Po trzecie, to respondent, a nie badacz określa, co jest ważne i adekwatne w kontekście dyskutowanego problemu (Aberbach i Rockman 2002).

Niewątpliwą słabością przyjętej metody jest zawężona perspektywa pojedynczego wywiadu. Wywiad to wąskie okno, przez które widać zaledwie fragment istniejących znaczeń i interpretacji. Tymczasem ze strony respondentów o statusie elit udzielenie godzinnego wywiadu jest sporym poświęceniem, stąd rzadko można liczyć na dłuższy czas osobistego kontaktu. Aby rozszerzyć perspektywę badawczą i sprawdzić słuszność wstępnych interpretacji, wywiady zostały przeprowadzone w czasie półtorarocznego uczestnictwa badaczki w życiu akademickim wybranych uczelni. Badaczka przyjęła afiliację jednej z uczelni na okres tego stażu. Uczestniczyła wówczas w kongresach, konferencjach i innych wydarzeniach poświęconych problematyce uniwersyteckiej; była też gościem na spotkaniach akademickich ciał kolegialnych wybranych uczelni. Podjęła wszelkie wysiłki, by zanurzyć się w społecznym świecie uczestników badań, co zaowocowało m.in. zaproszeniami na zamknięte spotkania organizowane zarówno przez uczelnie, jak i przez Konferencję Rektorów Akademickich Szkół Polskich. Obserwacje etnograficzne z tych wydarzeń znacznie wzbogaciły zasoby empiryczne zgromadzone w czasie wywiadów elitarnych.

\section{Wybrane wyniki badań}

Przedstawione wyniki są niewielkim wycinkiem większego projektu, prezentującym główne zagadnienie, jakim jest wizja przyszłości polskiego uniwersytetu, ukazana w ogólnym zarysie wraz z przykładami ilustrującymi główną tezę.

Wyniki badań wskazują, że respondenci w różny sposób diagnozują polskie uczelnie, co bierze się z odmiennych koncepcji ich misji. Zdaniem większości przedstawicieli władz akademickich ujętych w tym badaniu posłannictwem uczelni jest poszukiwanie prawdy i formacja intelektualna w relacji mistrz - uczeń. Tym- 
czasem respondenci w próbie rządowej uważają niemal zgodnie, że szkolnictwo wyższe istnieje głównie po to, by pomnażać publiczne i prywatne korzyści. Choć te dwie wizje wzajemnie się nie wykluczają, ich dotychczasowe interakcje prowadziły niejednokrotnie do rozwiązań niesprzyjających realizacji żadnego z tych celów.

\subsection{Prawda}

To jest misja uniwersytetu, że prawdę trzeba głosić i przeciwstawiać się błędowi. To jest najlepsze określenie misji uniwersytetu (A 206:28).

Koncepcje władz uczelni pokrywały się z wizją uniwersytetu stworzona przez wielkiego reformatora Wilhelma von Humboldta. Kształcenie jest w tym modelu rozumiane jako całościowa formacja nierozerwalnie związana z prowadzeniem badań naukowych. Główną wartością jest prawda, do której dochodzi się wspólnie i bezinteresownie:

[...] na bezinteresowności polega istota uniwersytetu (A 217:43) .

Respondenci akademiccy zdawali sobie przy tym sprawę, że aby poszukiwać prawdy i całościowo kształcić, uczelnie muszą stosować się do reguł rynku, który zapewnia potrzebne na ten cel środki. Na wszystkich uczelniach poza uczelnią techniczną rynek był postrzegany jako nieuchronna rzeczywistość, która nie powinna jednak wpływać na ideowe postrzeganie misji. Stąd kierunki studiów tworzone są przede wszystkim nie na podstawie badań rynku, lecz kryteriów ustanawianych w ramach dyscyplin naukowych, a badania stosowane, choć cieszą się dziś większym szacunkiem niż kiedyś z uwagi na związane z nimi korzyści, bywają traktowane jako „gorszy rodzaj nauki” (207:31).

Władze akademickie dostrzegają potrzebę kształcenia praktycznego i zawodowego. Jednak $\mathrm{w}$ przyjętej próbie żaden $\mathrm{z}$ badanych, w tym przedstawiciele uczelni specjalistycznej i zawodowej, nie postrzega tego zadania jako priorytetu swojej uczelni. Negatywne postrzeganie powiązań z rynkiem i masowości kształcenia było często wyrażane na wszystkich uczelniach oprócz uczelni technicznej. Oficjalne misje uczelni specjalistycznej i zawodowej odnoszą się do kształtowania praktycznych kompetencji, lecz ich reprezentanci twierdzili, że chętnie wyeliminowaliby przymiotniki ze swoich nazw i zostaliby „normalnymi” uniwersytetami. Tradycyjny uniwersytet badawczy jest normatywnym ideałem, co ilustruje nawet wypowiedź ekspertki rządowej zaniepokojonej tym, co w literaturze przedmiotu nazywa się ,akademickim dryfem” uczelni:

To jest pewnego rodzaju schizofrenia, bo rzeczywiście w pamięci, co często znajduje odzwierciedlenie w misjach, szkoły wyższe odwołują się do idei uniwersytetu humboldtowskiego. Uniwersytet badawczy się nie przeżył i nie skończył, ale w Polsce możemy powiedzieć 
- nie zaryzykuję liczb, ale niewiele uczelni może pretendować do miana uniwersytetu humboldtowskiego. Czasami jest tak, że w tej samej uczelni mamy jednostki, centra, które są silnie badawcze, i w tym się specjalizują, w badaniu i kształceniu przyszłych kadr naukowych i innowacyjnych. A więc fragment jest taki, który odpowiada tej kategorii. Natomiastreszta niestety, albo nie wiem, czy niestety, bardziej jest oddana trzeciej misji, czyli bardziej jest oddana pełnieniu bezpośredniej służby społecznej. I to widać gołym okiem. Jeżeli mała, lokalna szkoła, w pełni zintegrowana z lokalnym środowiskiem pracy, współpracująca z pracodawcami i z administracją lokalną, chciałaby być uniwersytetem humboldtowskim, to to jest zupełne nieporozumienie (109:8).

W powyższej wypowiedzi uderza to, że respondentka sama poprawia swoje stwierdzenie, że większość uczelni jest „niestety, albo nie wiem, czy niestety” przeznaczona do spełniania misji wspomagania lokalnego środowiska pracy. W jej krytyce lokalnych uczelni za pretendowanie do humboldtowskiego ideału wybrzmiewa silnie dominacja tego ideału. „Normalna” uczelnia to tradycyjny uniwersytet; reszta „niestety” musi zajmować się zadaniem służenia gospodarce. Taki wzorzec wynosi ze swojej uczelni większość kadry naukowo-dydaktycznej:

[...] jak Pani spojrzy na kadrę tych uczelni właśnie nazwijmy to typu szkoły zawodowe, nie mówiąc o uczelniach niepublicznych, to jest kadra, która przeszła z dużych uniwersytetów publicznych [...] no więc kadra pochodzi i jest wychowana na takich wzorcach (213:46).

\subsection{Korzyść}

Twórcy polskiej polityki naukowej wychodzili z innych założeń niż władze uczelni, a ich przekonania zbliżone były do anglosaskiej koncepcji uniwersytetu rynkowego. Szkolnictwo wyższe istnieje ich zdaniem po to, by pomnażać publiczne i prywatne korzyści. Korzyści te mogą być tak różnorodne jak samo społeczeństwo. Uczelnie mogą być dobre w wielu różnych obszarach: od prowadzenia badań podstawowych po zapewnianie studentom dobrych kontaktów towarzyskich. Natomiast z punktu widzenia państwa najważniejszym zadaniem uczelni jest przygotowanie absolwentów do wejścia na rynek pracy i wspomaganie gospodarki przez rozwój innowacji:

[...] kształcenie powinno zapewnić absolwentowi miejsce pracy, a gospodarce rozwój (105:59).

Celem uczelni jest służyć społeczeństwu poprzez współpracę z pracodawcami i reagowanie na potrzeby lokalnego rynku pracy. Dobrze funkcjonujące uczelnie przyczyniają się do tego, by absolwenci byli w stanie znaleźć zatrudnienie, a pracodawcy mieli dostęp do wysoko wykwalifikowanej kadry. Eksperci rządowi afiliowani w instytucjach akademickich podkreślali przy tym, podobnie jak przedstawi- 
ciele władz akademickich, że uczelnie nie powinny przygotowywać studentów do wykonywania konkretnego zawodu, ponieważ ich zawód prawdopodobnie kilka razy się zmieni - ale powinny kształtować kompetencje, które będą im służyły bez względu na wykonywany zawód:

Błędem jest myślenie że uniwersytet ma dawać zawód. Uniwersytet ma dawać wykształcenie (110:17).

Zdaniem respondentów z próby rządowej uczelnie nie mogą być rozliczane bezpośrednio z tego, czy ich absolwenci znajdą pracę, ale powinny stale zwracać uwagę na kompetencje potrzebne na dynamicznym i globalnym rynku pracy, takich jak: krytyczne myślenie, przedsiębiorczość i kompetencje międzykulturowe. Frazą, która często pojawiała się w wywiadach, było „reagowanie” i „odpowiadanie” na potrzeby społeczeństwa i rynku. Architekci reform z lat 2009-2011 twierdzili, że ich głównym celem było dostosowanie systemu szkolnictwa do potrzeb rynku pracy oraz wsparcie badań o większym potencjale komercyjnego zastosowania. Jedna z osób, które odegrały kluczową rolę w kształtowaniu kierunku reform, powiedziała:

[...] są oczywiście pewne zmiany dla studenta, żeby student miał lepsze umiejętności, żeby właśnie jego kształcenie było bardziej dostosowane do potrzeb rynku pracy, żeby zmieniła się struktura kierunków studiów, uczelni na te bardziej ścisłe, te, które są poszukiwane. Oczywiście nie zapominając o podstawach nauki. Dla naukowców żeby mogli również lepiej prowadzić badania, żeby bardziej włączyli się do międzynarodowych badań i żeby była większa integracja z gospodarką przy tych badaniach (105:68).

\subsection{Interakcje}

Kiedy przedstawiciele rządu wspominali o „dostosowaniu” kształcenia do potrzeb społeczeństwa i rynku, zwykle wiązało się to z krytyką środowiska akademickiego, które postrzegali jako zamknięte i zorientowane na interesy kadry naukowo-dydaktycznej. Szczególnie hamujące zdaniem respondentów są senaty uczelni, które działają zachowawczo i powstrzymują działania uważane za niestandardowe z punktu widzenia tradycyjnej nauki. Sposobem rządu na zmuszenie uczelni do zmiany są instrumenty prawne, które niektórzy politycy oceniali jako represyjne:

Powiedziałbym takie represyjne trochę podejście, że na przykład za dużo tych wieloetatowości, to zabronimy wieloetatowości. Jest za dużo nepotyzmu, to zabronimy nepotyzmu. W tym stylu (108:6).

Presja ze strony rządu, aby dostosować sposób kształcenia do zmieniającej się rzeczywistości, była przez respondentów akademickich postrzegana zdecydowanie negatywnie. Reakcją środowiska akademickiego na próby prawnego narzucenia 
nowych form studiów i współpracy z rynkiem są zachowania kompensacyjne polegające na obchodzeniu przepisów i tworzeniu pozorów. Dotyczą one w równym stopniu praw postrzeganych jako sprzeczne z etosem akademickim, jak i takich, których zasadność jest na uczelniach dostrzegana, ale razi biurokratyczny sposób ich wdrażania przez urzędników:

Czego nie można powiedzieć o środowisku akademickim, to są inteligentni ludzie. Urzędnik nie wygra z naukowcem. Urzędnik wyjdzie z parametrami, naukowiec się dostosuje i bezsensowne przepisy obejdzie. Jeżeli urzędnik wyda naukowcowi taką grę, to naukowiec ją wygra. Mnożenie zasad i biurokratycznych wymagań powoduje, że mnożą się dziury w systemie i sposoby ich obchodzenia (222:14).

Kultura organizacji, w których powszechne staje się obchodzenie przepisów i tworzenie pozorów, jest sprzeczna z etosem, którego środowisko akademickie próbuje w ten sposób bronić. Tworzy się tym samym błędne koło - społeczeństwo i rząd postrzegają środowisko akademickie jako jeszcze bardziej niezdrowe, co prowadzi do opracowywania kolejnych regulacji, które znów są obchodzone.

Tymczasem, jak zauważają sami uczeni, wysoki prestiż społeczny kadry profesorskiej sprawia, że część środowiska akademickiego ma możliwość wywierania istotnego wpływu na kształt polityki ministerstwa. Wywierają go nie tylko poprzez różnego rodzaju ciała eksperckie i doradcze, lecz również przez odwołanie do osobistego autorytetu, który w przypadku profesora uniwersytetu jest dużo wyższy niż w przypadku polityka. Jednym z przykładów skutecznego wpływu autorytetów z wiodących uczelni na politykę publiczną był związany z debatą na temat zniesienia habilitacji - głównego elementu strukturalnego humboldtowskiego uniwersytetu. Osoba uczestnicząca w procesie decyzyjnym stwierdziła, że ówczesna minister była bliska decyzji o zniesieniu habilitacji, lecz szanowany profesor jednego z najlepszych uniwersytetów zebrał grupę naukowych autorytetów i przyjechał na osobistą rozmowę w ministerstwie:

No i przyszli tu do pani minister i niestety minister pod wpływem już takiego grona profesorów najlepszych uczelni zrezygnowała z prowadzenia takiej całościowej rezygnacji z habilitacji, chociaż zrobiliśmy uproszczoną i przyspieszoną (105:55).

Wśród respondentów tego badania procedura habilitacyjna wypracowana w następstwie wspomnianych wydarzeń budzi zdecydowany sprzeciw - zarówno zwolenników modelu humboldtowskiego, jak i modelu rynkowego, i jest uważana za nieudane rozwiązanie kompromisowe.

Obecność logiki humboldtowskiej w polityce naukową nie ogranicza się do osobistych interwencji profesorów. Reformy systemu szkolnictwa wyższego były od wczesnych lat 90. XX wieku projektowane głównie przez ekspertów wywodzących się z tradycyjnych uniwersytetów, którzy wpisali elementy humboldtowskiej logiki w prawa, nowelizacje i rozporządzenia. Ich przykładem są zapisy o minimum ka- 
drowym. Zakłada się - co ma uzasadnienie w przypadku uczelni badawczej - że zatrudnienie dużej liczby pracowników naukowych posiadających stopnie naukowe doktora i doktora habilitowanego wpływa pozytywnie na jakość prowadzonego kształcenia. Założenie to nie sprawdza się jednak w przypadku uczelni zawodowych, w których prawny wymóg zatrudnienia na danym kierunku przynajmniej dwóch doktorów habilitowanych i czterech doktorów znacznie ogranicza możliwości prowadzenia studiów odpowiadających potrzebom rynku pracy.

Przykładem jest sytuacja opisana przez respondentów w uczelni zawodowej, która próbowała bez skutku otworzyć studia na kierunku informatyka. Do otwarcia kierunku nie doszło, ponieważ nie udało się zebrać minimum kadrowego. Pozyskanie doktorów informatyki okazało się niemożliwe, ponieważ ich średnie zarobki są cztery razy wyższe niż byłaby im w stanie zaproponować uczelnia, a osoby ukierunkowane naukowo nie widziały dla siebie na uczelni zawodowej możliwości awansu $(220,223)$. Zdaniem władz uczelni planowane studia byłyby nie tylko dużo bardziej możliwe w realizacji, ale też lepsze, gdyby zajęcia mogli prowadzić praktycy ze stopniem magistra, lecz władze uczelni były zmuszone poszukiwać osób z doktoratami, choćby z innych dyscyplin, w których posługuje się technologią informacyjną, jak fizyka kwantowa. Mimo że udało się znaleźć kilka takich osób, uczelnia nie dostała pozwolenia na prowadzenie studiów, ponieważ nie spełniała wymogów minimum kadrowego. Z podobnych względów nie udało się uruchomić dwóch innych kierunków, na które jest zapotrzebowanie w regionie. W efekcie uczelnia prowadzi studia nie na takich kierunkach, na które jest popyt, lecz na takich, do których są osoby do minimum kadrowego. Są to głównie kierunki akademickie, takie jako politologia i filologia. Jedna z przedstawicielek władz uczelni stwierdziła otwarcie:

[...] to są akademickie dyscypliny i generalnie nic wspólnego nie miało z zawodowością [...] Mamy świadomość tego, że produkujemy bezrobotnych $(221: 15,32)$.

Nawet w reformie z 2011 r., której założeniem było bliższe powiązanie uczelni ze środowiskiem społeczno-gospodarczym, autonomię tworzenia nowych kierunków bez konieczności uzyskania pozwolenia z ministerstwa przyznano ośrodkom posiadającym uprawnienia do nadawania stopnia naukowego doktora habilitowanego, a formuła finansowania sprzyja uczelniom o profilu akademickim:

Siła jest, jeśli chodzi o nadawanie stopni i tytułów naukowych [...] Z tego jest większa autonomia, a ponadto dotacje są inne na dydaktykę. Prestiż jest inny z tego powodu, że możemy kadrę kształcić dla siebie i dla innych. W rankingu i w algorytmie finansowania na działalność dydaktyczną to się liczy (218:56).

Podsumowując, władze akademickie i twórcy polityki naukowej uczestniczący w tym badaniu dążą do poprawy kondycji polskiego szkolnictwa za pomocą mechanizmów rządzących się różną logiką. Mechanizmy te wchodzą ze sobą w nie- 
pożądane interakcje, które sprawiają, że w przeciwieństwie do sytuacji chwalonej w polskim przysłowiu, wilk chodzi głodny, a owca jest na wpół zjedzona. Tymczasem cele stawiane szkolnictwu przez przedstawicieli władz państwowych i akademickich się nie wykluczają, a ich realizacja jest niezbędna do prawidłowego funkcjonowania sektora szkolnictwa wyższego.

\section{Obszary potencjalnej synergii}

Istnieją trzy obszary, które mogą stać się punktami zwrotnymi w funkcjonowaniu systemu szkolnictwa, w którym prawda i korzyść tworzą synergię zamiast konkurować o prawo do wyłączności. Samo istnienie tych obszarów nie gwarantuje udanej przemiany, a przemiana jest w oderwaniu od takich zbieżności mało prawdopodobna. Sferami, od których może rozpocząc się pozytywna transformacja polskiego szkolnictwa, są: kształcenie elitarne, merytoryczne finansowanie badań oraz kompetencje „miękkie”.

\subsection{Kształcenie elitarne}

Pierwszy obszar, gdzie widzimy wyraźnie, że pojęciowe ramy, którymi posługują się decydenci, wydają się ze sobą zbieżne, to obszar kształcenia elitarnego. Decydenci polityczni i władze uczelni wydają się zgodni co do tego, że Polsce brakuje kształcenia przygotowującego do pełnienia wiodących ról w różnych obszarach społecznych, a także co do tego, że kształcenie elit powinno być raczej ogólne niż specjalistyczne i że wymaga silnej relacji uczeń - mistrz. W związku z tym prawdopodobne jest, że reformy zmierzające do większej dywersyfikacji szkolnictwa wyższego, z naciskiem na wzmocnienie kształcenia elitarnego, zyskają większą aprobatę tych ważnych interesariuszy.

Trudności związane z kształtowaniem elitarnych programów oraz instytucji są dwojakie. Po pierwsze, elitarne programy są przeznaczone dla niewielkiej liczby studentów i muszą być prowadzone przez wykładowców o najwyższych kwalifikacjach, co sprawia, że są drogie w utrzymaniu. Po drugie, hojniejsze finansowanie jednych programów niż innych może być postrzegane jako sprzeczne z ważną w polskiej kulturze wartością, jaką jest egalitaryzm. Inwestowanie większych środków w programy na najwyższym poziomie nie ma wielkich szans na polityczną akceptację, jeżeli będzie odbywać się kosztem innych programów lub instytucji. Chociaż kluczowi interesariusze zdają sobie sprawę, że niektóre programy i instytucje szkolnictwa wyższego mogłyby i powinny zostać wyeliminowane, nikt nie zagłosuje za zlikwidowaniem własnego miejsca pracy. Jak ujął to jeden z respondentów: „Wszyscy się zgadzają, że jakieś pociski atomowe powinny być, ale nie na moim terenie: (207:93). Zamknięcie programów i instytucji niegenerujących 
wartości innych niż zatrudnienie osób, które w nich pracują - a respondenci w badaniu przyznali, że takowe istnieją - wymagałoby wielkiej odwagi politycznej.

Bardziej problematyczny w koncepcjach misji szkolnictwa wyższego, w którym nie ma oczywistych punktów stycznych, jest postulat, by instytucje szkolnictwa wyższego przygotowywały absolwentów do działalności zarobkowej. Podczas gdy osoby odpowiedzialne za politykę państwa obstają przy tym, że zatrudnialność jest nieodzownym rezultatem, a większość studentów dąży do uzyskania wyższego wykształcenia w tym właśnie celu, idea ta stoi w sprzeczności z misją przyjmowaną przez władze uczelni i głęboko zakorzenioną w strukturach akademickich. Możliwe, że system szkolnictwa wyższego musiałby zostać uzupełniony o nowe struktury, aby misja promowania zatrudnialności znalazła w innym miejscu prestiżowe instytucjonalne oparcie.

\subsection{Merytoryczne finansowanie badań naukowych}

Prowadzenie przełomowych badań poszerzających aktualny stan wiedzy leży u podstaw tego, co przedstawiciele świata akademickiego uważają za tożsamość instytucji szkolnictwa wyższego; jest ono także cenione z uwagi na potencjalną maksymalizację publicznych korzyści ze szkolnictwa wyższego. $Z$ ideowego punktu widzenia zarówno środowiska akademickie, jak i te decydujące o polityce państwa zdają się wyznawać pogląd, że finansowanie badań naukowych powinno być rozdzielane według kryterium merytorycznego, a nie na podstawie indywidualnych cech czy przynależności naukowców do danej instytucji.

Jeśli chodzi o budowanie synergii między poszukiwaniem naukowej prawdy a pomnażaniem społecznych korzyści z nauki, głównymi instytucjami powołanymi w tym celu są agencje finansowania nauk podstawowych i stosowanych: Narodowe Centrum Nauki (NCN) oraz Narodowe Centrum Badań i Rozwoju (NCBiR). Jako nowe agencje, niezależne od Ministerstwa Nauki i Szkolnictwa Wyższego, korzystające w swoich procedurach recenzji naukowej z ekspertyzy samych naukowców, mają szansę zyskać większą legitymizację społeczną niż ministerstwo lub jakakolwiek inna agenda rządowa. Powodzenie tych instytucji zależy od tego, jak postrzegana będzie rzetelność i przejrzystość metod stosowanych do oceny merytorycznej wniosków o granty, a także zobowiązania rządu do dystrybucji większości przyszłych środków na badania naukowe poprzez niezależne instytucje, a nie kanały polityczne. Niezależne agencje dysponują obecnie mniej niż połową krajowego budżetu na badania. Zakładając stałe zaangażowanie w zachowanie rzetelności przyjętych procedur, skala działalności tych agencji może i powinna być rozszerzana. 


\subsection{Kompetencje „miękkie“}

Trzecia potencjalna ścieżka transformacji łączącej wartości humboldtowskie z rynkowymi skupia się na pojęciu „miękkich” kompetencji - umiejętności mających ogólne zastosowanie, takich jak: krytyczne myślenie, praca zespołowa, komunikacja międzykulturowa, zdolność wyszukiwania wiarygodnych informacji lub szybkiego dostosowywania się do nowych sytuacji. Istnieje powszechna zgoda co do tego, że takie kompetencje są nie tylko podstawą ogólnego kształcenia opartego na humanistycznych wartościach, ale także praktycznego szkolenia pracowników na szybko zmieniający się rynek pracy, gdzie zatrudnienie w jednym miejscu przez większą część kariery zawodowej nie jest już zasadą, a raczej wyjątkiem. Potrzebę uwzględnienia umiejętności, które można wykorzystywać na wszystkich etapach i szczeblach życia zawodowego, dostrzega się w Polsce nawet w instytucjach tradycyjnie skupiających się na kształtowaniu umiejętności technicznych oraz zawodowych - zmianę tę ilustruje wprowadzenie obowiązkowych przedmiotów humanistycznych na jednej z wiodących politechnik (Tadeusiewicz 2014).

Trudność w kształtowaniu „miękkich” kompetencji w polskim szkolnictwie wyższym wiąże się ze sposobem ich nabywania - odbywa się to poprzez doświadczenie i praktykę. Wyklucza to możliwość wprowadzenia ich poprzez uzupełnienie programu nauczania o nowe treści. Przekazywanie umiejętności pracy zespołowej lub komunikacji międzykulturowej wymaga innego rodzaju pedagogiki niż tradycyjny wykład uniwersytecki, a jeśli wykładowcy mają promować takie kompetencje wśród swoich studentów, muszą najpierw sami je posiąść. W Polsce kontrowersje wzbudziło wprowadzenie przez rząd prawa nakazującego włączenie „kompetencji społecznych" w cele poszczególnych przedmiotów, pozostawiające instytucjom szkolnictwa wyższego niewiele czasu i środków na jego wdrożenie oraz niezapewniające wystarczającego zaplecza szkoleniowego, by w sensowny i spójny sposób ująć takie kompetencje w planowaniu struktury nauczanych przedmiotów. Kształtowanie „miękkich” kompetencji wydaje się jeszcze bardziej odporne na odgórne regulacje niż inne aspekty praktyki nauczania; wręcz przeciwnie - niezamierzonym skutkiem ubocznym tego typu działań jest zniechęcenie kadry naukowej do pomysłów, z którymi w innych okolicznościach być może w pełni by się zgodzili.

\section{4. Ślepe uliczki}

Kwestia, czy postulowane obszary staną się podstawą synergicznych przemian, zależy w dużym stopniu od przyjętej strategii działania. Na podstawie ustaleń wynikających z prezentowanego badania warto rozważyć trzy „ślepe uliczki”, które dotąd się nie sprawdziły i mają nikłe szanse powodzenia w przyszłości. 


\subsection{Radykalne operacje}

Do tej pory w kręgach polskiej polityki nauki można było zaobserwować silną pokusę sięgania po rozwiązania odgórne, wdrażane za pomocą przepisów i regulacji, co jest równoznaczne z optowaniem za wysłaniem chorego „pacjenta” na „operację”. Nadmierne wykorzystywanie zakrojonych na szeroką skalę regulacji nie przyniosło dotąd spodziewanych efektów. Widać to szczególnie po liczbie zmian legislacyjnych w polskim szkolnictwie wyższym ostatnich lat, które doprowadzily do poczucia zmęczenia reformami. W latach 2009-2011 środowisko akademickie miało trudności z nadążaniem za kolejnymi przepisami i dyrektywami, a każdy wysiłek reformatorski pogłębiał wrażenie, że poprzedni był niepełny. Powstawało również poczucie, że nowe rozwiązania nie miały czasu dojrzeć i wydać owoców, a już zostały zastąpione jeszcze nowszymi mechanizmami. Niezależnie od tego, czy wrażenie to jest trafne, czy nie, samo jego występowanie zwiększa prawdopodobieństwo, że kolejne reformy istniejącego systemu w najbliższej przyszłości spotkają się z pretensjami, unikami, a nawet próbami obalenia przez kadrę akademicką.

Zmęczenie reformami stawia kolejnych ministrów nauki i szkolnictwa wyższego w trudnej sytuacji. Po dwóch kadencjach energicznych wysiłków reformatorskich najbardziej asertywnego z dotychczasowych ministrów utrzymuje się przeświadczenie, że system jest „chory” - przy czym niektórzy uczeni odnoszą wrażenie, że „choroba” ta rozwinęła się do postaci „zarazy” (Modzelewski 2014). Poczucie kryzysu rośnie także w społeczeństwie. Od 2004 do 2009 r. odsetek Polaków przekonanych, że warto dążyć do uzyskania wyższego wykształcenia, spadł o 13\% (OBOP 2009). Z kolei 37\% polskiego społeczeństwa jest aktualnie zdania, że uczeni „kłamią na temat swoich badań dla osobistych zysków”, a 28\% uważa ich za „niebezpiecznych” - są to najwyższe odsetki w grupie obejmującej kraje Unii Europejskiej oraz Stany Zjednoczone (BBVA 2011). Z uwagi na spadający poziom zaufania społecznego do systemu szkolnictwa wyższego, rząd wybrany w wyborach w 2015 r. stanie przed pokusą, by zdecydować się na radykalne operacje. Zdecydowane działania są z pewnością niezbędne w niektórych obszarach - jest to szczególnie potrzebne w kwestii nierzetelności akademickiej. Chociaż solidne dane empiryczne na ten temat są znikome, zarówno w społeczeństwie, jak i wśród naukowców zdaje się dominować pogląd, że problem znacznie się zwiększył wraz z umasowieniem szkolnictwa. Fakt, że 37\% społeczeństwa jest zdania, iż uczeni kłamią w celu osiągnięcia osobistych korzyści, jest niepokojący; aby instytucje szkolnictwa wyższego mogły funkcjonować jako instytucje zaufania publicznego, należy szybko i bez znieczulenia przeprowadzać „operacje” rugujące z uczelni zachowania nieetyczne i niezgodne z akademickim obyczajem.

Równocześnie trzeba pamiętać, że „operowanie” systemu szkolnictwa wyższego odbywa się na żywym i w pełni przytomnym organizmie. W maju 2014 r. „pa- 
cjent” wydawał się bardzo osłabiony w wyniku stosowania wielu różnych, czasem kolidujących ze sobą kuracji. Nie ma żadnej wątpliwości, że niebezpieczne guzy muszą zostać wycięte - potrzebny jest jednak do tego skalpel, a nie topór. Jak sugerowano wcześniej, można i należy unikać operowania w obszarach, gdzie te same cele mogą być osiągnięte za pomocą diety, która wzmocni to, co korzystne, i „zagłodzi” to, co szkodliwe.

\subsection{Jednolite struktury dla różnych celów}

Drugą kwestią, którą warto wziąć pod uwagę, jest to, że systemy społeczne zazwyczaj generują wyniki zgodne z tym, do czego zostały stworzone. Według teoretyka systemów Richarda Buckminstera Fullera: „Zmian nigdy nie wprowadza się poprzez walkę z zastaną rzeczywistością. Żeby coś zmienić, należy zbudować nowy model, który zdezaktualizuje poprzedni" (Fuller Buckminster, n/d). Kształtowanie umiejętności potrzebnych na rynku pracy nie jest celem wpisanym w tradycyjny model polskich uczelni - jest jednak zasadniczy, jeśli chodzi o tożsamość wielu innych instytucji, które pojawily się w Polsce od lat 90. XX wieku. Prywatne instytucje szkolnictwa wyższego, organizacje pozarządowe i fundacje mające na celu wypełnienie tej niszy powstały przy niewielkim lub żadnym wsparciu ze strony rządu. Niektóre z nich opracowały wysoce innowacyjne programy zasługujące na rządowe wsparcie. Jedną z takich instytucji jest Akademia Leona Koźmińskiego - prywatna placówka w Warszawie, która znalazła się na liście 20 uczelni oferujących najlepsze studia magisterskie $\mathrm{w}$ dziedzinie globalnych finansów, przygotowanej przez „Financial Times”, a także została uznana za najlepszą szkołę biznesową w Europie Środkowej i Wschodniej (Financial Times, 2013). Bardziej kontrowersyjnym przykładem jest ASBIRO - alternatywna instytucja skupiająca się na lokalnym biznesie i przedsiębiorczości, która przyciąga rzesze studentów, ogłaszając, że wszyscy jej wykładowcy są przedsiębiorcami, a nie naukowcami (ASBIRO, 2014). Jednostki takie są przykładem nowych struktur organizacyjnych zbudowanych w ciągu ostatnich dwudziestu lat w celu odpowiedzenia na te same potrzeby, do spełniania których rząd próbował zmusić tradycyjne uniwersytety. Z uwagi na wątpliwe efekty dotychczasowych starań architekci polityki państwa powinni rozważyć dywersyfikację inwestycji publicznych środków w różne typy struktur edukacyjnych służące różnym celom. Nie ulega wątpliwości, że tradycyjne uniwersytety nadal odgrywają istotną rolę w poszerzaniu horyzontów wiedzy i przygotowywaniu wszechstronnie wykształconych elit. Być może jednak nadszedł czas, by przestać oczekiwać od nich kształcenia zawodowego, szczególnie że istnieją już innego typu instytucje szkolnictwa wyższego o udokumentowanych osiągnięciach, które mogłyby okazać się warte zainwestowania publicznych środków. Podejściem, które nie zostało jeszcze wypróbowane, jest oferowanie funduszy zalążkowych dla dobrze rokujących programów realizujących deficytowe cele w szkolnictwie wyższym, które mogłyby 
zostać rozwinięte w nowe modele organizacyjne. Ta sama zasada dotyczy nowych struktur organizacyjnych w ramach istniejących instytucji - zachęcanie ludzi do stosowania rozwiązań, z którymi mieli wcześniej wyłącznie negatywne doświadczenia (jak w przypadku propozycji wprowadzenia rad powierniczych), przynosi efekty odwrotne do zamierzonych.

Uznanie potrzeby powołania różnych struktur do różnych celów pociąga za sobą zróżnicowane podejścia pod względem przepisów i systemów nagradzania. Zawodowe uczelnie podlegają obecnie podobnym prawom co tradycyjne uniwersytety i chociaż czyni się dla nich pewne wyjątki, w praktyce instytucje te są traktowane jak gorsze wersje idealnego wzoru, którym jest wszechstronny uniwersytet. Na przykład, jak wskazywali badani, akademickie osiągnięcia wymagane do uzyskania doktoratu czy habilitacji mają znikome przełożenie na jakość programów skupiających się na praktyce, gdzie orientacja taka może być wręcz ciężarem. Dopóki programy akademickie będą w prawie traktowane jako wzorzec, „dryf akademicki” instytucji niebędących uniwersytetami będzie się utrzymywał, a kolejne specjalistyczne uczelnie będą dążyły do uzyskania statusu uniwersytetu. W Polsce potrzebne są środki do zwiększania prestiżu praktycznie zorientowanego szkolnictwa poprzez inwestowanie w wybrane, wyjątkowo obiecujące programy, a także ograniczenie przepisów na tyle, aby instytucje niebędące uniwersytetami miały dość przestrzeni, by efektywnie prosperować. Złagodzenie przepisów byłoby dobrą wiadomością dla wszystkich innych typów instytucji szkolnictwa wyższego, bo umożliwiłoby większą dywersyfikację oraz skupienie się każdej instytucji na tym, w czym jest rzeczywiście najlepsza.

\subsection{Kosztowne skróty}

Ostatnią kwestią, jaką warto wziąć pod uwagę zarówno przy planowaniu polityki państwa, jak i zarządzaniu uczelniami, jest to, że w krajach posttransformacyjnych, takich jak Polska, do wzmocnienia instytucji publicznych nie można dojść na skróty. Bezkrytyczne zapożyczanie form organizacyjnych, które sprawdziły się w innych obszarach globu, i przenoszenie ich na rodzimy grunt często nie tyle nie przybliża, ile wręcz oddala perspektywę realizacji zamierzonych celów. Narzucanie rozwiązań organizacyjnych postrzeganych przez osoby z wewnątrz jako wymuszone lub obce zazwyczaj wywołuje silną odpowiedź autoimmunologiczną, która działa później jak szczepionka przeciwko jakimkolwiek podobnym rozwiązaniom - nawet w przypadkach, gdy mogłyby się one okazać pomocne i stosowne.

Dynamikę tę dobrze ilustruje przypadek niedawnego kongresu organizacji pozarządowych w Krakowie, zorganizowanego przez władze miasta. Zainspirowana wizytami roboczymi w miastach Europy Zachodniej, pełnomocnik ds. organizacji pozarządowych uznała, że miasto potrzebuje rady doradczej organizacji pozarządowych. Zaprosiła przedstawicieli wszystkich takich organizacji zarejestrowanych 
w Krakowie, by przedstawić ideę rady. Kiedy uczestnicy kongresu dowiedzieli się wystarczająco wiele, by zacząc omawiać zalety i wady takiego rozwiązania, zostali podzieleni na grupy, w których profesjonalni moderatorzy zadawali im szczegółowe, techniczne pytania o to, jak rada powinna funkcjonować. Spotkanie zakończyło się głosowaniem za lub przeciw jej powstaniu. Plan odniósł skutek przeciwny do zamierzonego. Uczestnicy opuścili kongres z poczuciem, że zostali oszukani i zmanipulowani. Wiele osób odmówiło wzięcia udziału w głosowaniu - nie tylko z powodu obaw, że rada stanie się narzędziem manipulacji politycznej, ale że sam sposób, w jaki pomysł został zaprezentowany, był manipulacją (Dziewitek, 2014). Pomimo najlepszych chęci z obu stron, próba przyspieszenia implementacji sprawdzonej europejskiej praktyki okazała się krokiem wstecz we wzajemnej współpracy. Za wyjątkiem rewolucji, próby przyspieszenia transformacji mogą łatwo sprawić, że wysiłki zmierzające do reform spalą na panewce.

\section{Uwagi końcowe}

Jednym z cieni najnowszej historii Polski utrzymujących się nad współczesnymi instytucjami jest tendencja do uogólniania danej tożsamości czy pozycji i stawiania jej za uniwersalny wzór. Poprzednia epoka utrwaliła w polskim społeczeństwie narrację jednorodności, która przetrwała dzięki założeniu, że sytuacją pożądaną jest takie samo myślenie, taki sam światopogląd i takie samo postępowanie. Jednak podobnie jak ma to miejsce w świecie biologicznym, natura porządku społecznego i gospodarczego jest taka, że monokultury wróżą ekologiczną katastrofę. Różnorodność form instytucjonalnych w polskim szkolnictwie wyższym świadczy o jego potencjale, nie jest jednak jeszcze cechą charakterystyczną dominującej w systemie autonarracji.

Przez ostatnich dwadzieścia lat monopol na dominującą narrację miały tradycyjne uniwersytety, jednak monopol ten słabnie. Według Mirosławy Marody wiek, w którym tradycyjny humboldtowski uniwersytet odgrywał dominującą rolę w kulturze, dobiegł końca (Marody 2014). Uniwersytet jako depozytariusz czystej wiedzy musi przetrwać, a stanie się tak tylko wtedy, gdy zaakceptuje na scenie szkolnictwa wyższego rolę jednego spośród wielu aktorów. Jeśli natomiast będzie bronił swojej uprzywilejowanej pozycji jako jedynego wzorca, zostanie zepchnięty na taką samą marginalną pozycję, co fundamentalistyczne formy religii - zapomniane relikty przeszłości pozbawione łączności z głównymi nurtami życia.

\section{Literatura}

Aberbach, J.D., Rockman, B.A. (2002). Conducting and coding elite interviews. Political Science \& Politics. 35(4): 673-676. 
ASBIRO (2014). Jedyna szkoła, w której uczą wyłacznie przedsiębiorcy [The only school where all teachers are entrepreneurs]. http://www.asbiro.pl/ [4.04.2014].

Balcerowicz, L. (2014). Jakość i efektywność $w$ szkołach wyższych a systemy ich finansowania. Kongres Kultury Akademickiej. Kraków: Uniwersytet Jagielloński.

BBVA (2011). International Study on Scientific Culture: General Attitudes to Science. BBVA Foundation Department of Social Studies and Public Opinion. http://www.fbbva.es/TLFU/ dat/culturacientificanotadeprensalarga.EN.pdf [30.12.2015].

Bendyk, E. (2008). Płacz nad trumną. Polityka. http://www.polityka.pl/tygodnikpolityka/kraj/251169,1,placz-nad-trumna.read [30.12.2015].

Dexter, L.A. (1970). Elite and specialized interviewing. Colchester, UK: European Consortium for Politcal Research.

Dybczyński, A. (2011). Jestem baronem. Nie chcę dłużej żyć w średniowieczu. Gazeta Wyborcza http://wroclaw.gazeta.pl/wroclaw/1,35751,9022221,Jestem_baronem_Nie_chce_dluzej_ zyc_w_sredniowieczu.html [30.12.2015].

Dziewitek, P. (2014). Kolejny krok w tył we wspótpracy UMK i NGO. Stowarzyszenie Pracownia Obywatelska.http://pracowniaobywatelska.pl/kolejny-krok-w-tyl-we-wspolpracy-umk-i-ngo/ [30.12.2015].

Financial Times. (2013). Business school rankings from the Financial Times - Kozminski University. http://rankings.ft.com/businessschoolrankings/kozminski-university-warsaw/ [data].

Fullan, M. (2001). The new meaning of educational change. New York: Teachers College Press.

Fuller Buckminster (n/d). Buckminster Fuller Institute. http://www.bfi.org/about-bfi/updates/ 2014/03/countdown-begins [30.12.2015].

Geertz, C. (1973). The interpretation of cultures. New York: Basic Books.

Guba, E.G., Lincoln, Y.S. (2005). Paradigmatic Controversies, Contradictions, and Emerging Confluences. W: E.G. Guba, Y.S. Lincoln (red.). Handbook of Qualitative Research (191215). Thousand Oaks, CA: Sage.

Hartman, J. (2013). Umarła klasa. Gazeta Wyborcza. http://wyborcza.pl/magazyn/1,132517, 13885836,Umarla_klasa.html [30.12.2015].

Kwiek, M. (2012). Changing Higher Education Policies: From Deinstitutionalization to Reinstitutionalization of the Research Mission in Polish Universities. Science and Public Policy. 39(5): 641-654.

Marody, M. (2014). Etos, wartości i standardy w nauce akademickiej i „post-akademickiej”. Kongres Kultury Akademickiej, Kraków: Uniwersytet Jagielloński. http://kongresakademicki.pl/ [30.12.2015].

Menzel, H. (1978). Meaning: Who needs it? W: M. Brenner, P. Marsh, M. Brenner (red.). The social contexts of method (140-171). New York: St. Martin's Press.

Modzelewski, K. (2014). Humanistyka akademicka - misja czy komercja i biurokracja? Kongres Kultury Akademickiej, Kraków: Uniwersytet Jagielloński. http://kongresakademicki.pl/ [30.12.2015].

Newsweek (2014). Polacy na walizkach. Emigracyjny efekt domina. Newsweek. 23 marca. http:// polska.newsweek.pl/emigracja-z-polski-gdzie-wyjezdzaja-polacy-newsweek-pl,artykuly, 282624,1.html [30.12.2015].

OECD (2011). Stat Extracts: Graduates by field of education. http://stats.oecd.org/Index.aspx? DataSetCode=RGRADSTY [30.12.2015]. 
OBOP (2013). 2 miliardy. Sposób na bezrobocie. Warszawa: Energy for Europe, s. 16. http:// fede.org.pl/raport-2miliardy-sposob-na-bezrobocie/ [30.12.2015].

OBOS (2009). Rola wykształcenia i zmiany $w$ jej społecznym postrzeganiu $w$ latach 1993-2009 (BS/163/2009). Warszawa.

Ozminkowski, V. (2009). Uczelnie niższe. Newsweek. 5 grudnia. http://www.newsweek.pl/uczel nie-nizsze,49872,1,1.html [30.12.2015].

Pacholski, L. (2011). Byłem admirałem stojącej flotylli. Gazeta Wyborcza. http://wroclaw.gazeta.pl/wroclaw/1,35751,9058004,Leszek_Pacholski_Bylem_admiralem_stojacej_flotylli. html [30.12.2015].

Papuzińska, M. (2009). Kryzys polskich uczelni: Szkoły z kasą. Polityka, http://www.polityka.pl/ kraj/analizy/303296,1,kryzys-polskich-uczelni.read [30.12.2015].

Schwandt, T.A. (2000). Three epistemological stances in qualitative inquiry: Interpretivism, Hermeneutics, Social Constructivism. W: N.K. Denzin, Y.S. Lincoln (red.). Handbook of qualitative research (189-213). Thousand Oaks, CA: Sage.

Sztompka, P. (2014). Uniwersytet wspótczesny: Zderzenie dwóch kultur. Kongres Kultury Akademickiej. Kraków: Uniwersytet Jagielloński. http://kongresakademicki.pl/uniwersytet-wspolczesny-zderzenie-dwoch-kultur/ [30.12.2015].

Tadeusiewicz, R. (2014). Humanistyka: hamulec i kierownica. Panorama Polskiej Akademii Nauk. t. 6,nr 18.http://panorama.pan.pl/s,humanistyka-hamulec-i-kierownica,122.html[30.12.2015]. Thomas, W.I., Znaniecki, F. (1927). The Polish Peasant in Europe and America. New York: Alfred A. Knopf.

\section{Treatment worse than disease? Diagnosis through the study of public higher education elites}

ABSTRACT. The public system of higher education in Poland is widely seen as "ill" - incompatible with the aims assumed by its stakeholders. There is agreement as to the existence of the problem, but no agreement on the diagnosis or courses of treatment. The diagnosis presented in this article is based on a two-year study of higher education elites - academic leaders and government policymakers. The author proposes that a possible cause of the "illness" can be understood through the medical term of polypragmasia - a situation when a sick patient consults different doctors who provide different diagnoses and prescribe different medications that produce undesirable interactions. The university is "sick" because the Ministry of Science and Higher Education and academic leaders give it different "diagnoses" and prescribe different "medications." While academic leaders emphasize the role of the university in pursuing truth, policymakers see it primarily as an engine of economic growth. In effect, the aims pursued by academic leaders differ from those assumed in recent Polish legislation, and stimuli stemming from political channels encourage behaviors incompatible with the academic ethos. Research findings suggest three areas of potential synergy that could become turning points towards a self-transformation of Polish higher education: elite education, merit-based funding of academic research, and "soft skills."

KEYWORDS: higher education, university, science policy, governance, qualitative research

CYTOWANIE: Shaw, M. (2015). Leczenie gorsze od choroby? Diagnoza kondycji polskiego szkolnictwa wyższego w oparciu o badania elit polskich uczelni publicznych. Nauka i Szkolnictwo Wyższe. 1(45): 117-135. DOI: 10.14746/nsw.2015.1.5. 